\title{
Condition of Atlantic cod Gadus morhua larvae after the transition to exogenous feeding: morphometrics, buoyancy and predator avoidance
}

\author{
John D. Neilson, R. Ian Perry, Paul Valerio* \& K. G. Waiwood \\ Marine Fish Division, Fisheries Research Branch, Department of Fisheries and Oceans, Biological Station, St. Andrews, \\ New Brunswick EOG 2XO, Canada
}

\begin{abstract}
The condition of Atlantic cod Gadus morhua L. larvae reared in densities of 0, 2, 5 and 10 zooplankton $\mathrm{ml}^{-1}$ was examined after the transition to exogenous feeding. Fulton's $\mathrm{K}$ (weight/length ${ }^{3}$ ) was not correlated with prey density in which larvae were reared, indicating that this index of condition is inappropriate for larvae immediately after yolk sac absorption. Fulton's $\mathrm{K}$ was also not positively correlated with the ability to avoid a simulated predator. However, predation avoidance was positively correlated with higher prey density. A second measure of condition, body height standardized for length, appeared to be a more sensitive indicator of condition but also did not correlate with the ability of larvae to avoid predation. The results of a buoyancy experiment indicated that poorly fed larvae may occur higher in the water column, and thus may be more vulnerable to predation or cause a sampling bias in ichthyoplankton studies.
\end{abstract}

\section{INTRODUCTION}

Following Hjort's $(1914,1926)$ studies postulating the existence of a food-limited critical period for marine fishes during their larval development, many workers have pursued field studies with the objective of better defining the relation between prey abundance and survival. For example, Shelbourne's (1957) work on the feeding and condition of plaice larvae Pleuronectes platessa corroborated the view of Hjort, that fish from regions of good food supply were in better condition and in later developmental stages than those caught in areas of low prey density. Shelbourne speculated that the ultimate cause of death of larvae in regions of food limitation was an inability to furnish sufficient energy to meet osmoregulatory demands. The end of the yolk-sac phase and the transition to exogenous feeding is often suggested as a critical period (May 1974), with natural mortality increasing markedly in the absence of sufficient prey. However, measurements of the condition of larvae exposed to different prey concentrations during this period have not yet been obtained.

\footnotetext{
- Present address: Department of Biology, Memorial University of Newfoundland, St. John's, Newfoundland A1B 3X9, Canada
}

A variety of techniques have been employed to study larval condition, including histological (Ehrlich et al. 1976, O'Connell 1980), chemical (Ehrlich 1974a, b, Buckley 1979, 1980, O'Connell \& Paloma 1981), otolith microstructure examination (Methot 1982) and morphological measurements (Koslow et al. 1985). However, while such studies report a range of values for the indices of condition measured, there is often little evidence whether such differences are related to larval survival. Moreover, indirect effects of changes in larval condition, such as on buoyancy and the ability to avoid predation, have received limited attention.

Most studies of buoyancy of early life history stages have been concerned with eggs (Sundnes et al. 1964, Coombs et al. 1985). Differences in buoyancy have been used to distinguish the developmental stages of eggs of the same species and to distinguish between species (Coombs 1981). In an ecological sense, physical oceanographic mixing processes and differences in egg buoyancy have been used to infer the vertical distribution of eggs in the sea (Sundby 1983), which may ultimately be reflected in their horizontal distribution in areas with vertical current shear (Power 1984). Less work has been done on the buoyancy of fish larvae. Blaxter \& Ehrlich (1974) and Ellertsen et al. (1980) examined buoyancy changes of completely starved larvae to determine the 'point of no return', the 
point where larvae would not exhibit feeding behavior even if food were available. We are not aware of any studies involving buoyancy of early stages of larvae reared under different prey densities.

In this study we examine how 4 indicators of condition represent larval growth and potential for survival of Atlantic cod Gadus morhua L. during the transition to exogenous feeding. We examine the relative merit of 2 morphometric condition factors, Fulton's K (LeCren 1951) and body height expressed as a function of length (Theilacker 1978, Koslow et al. 1985). We also consider the use of larval buoyancy measurements and the ability to avoid predation as indicators of condition, both of which likely depend on success of recent feeding and have important implications for larval survival.

\section{METHODS}

Milt and unfertilized eggs were obtained by handstripping captive adult cod brood stock maintained at the St. Andrews Biological Station. Within 3 to $5 \mathrm{~min}$ of stripping, seawater was mixed with the gametes while chilling the mixture over an ice bath. A measured volume of eggs was then transferred to four $39 \mathrm{l}$ tanks which were used for both incubation and rearing. The tanks were of rectangular, fiberglass construction, painted black inside to minimize reflection and subsequent phototactic-related concentration of larvae and to provide sufficient contrast for larvae to visually locate their prey (J. Blaxter pers. comm.). The temperature of circulating filtered seawater supplied to the tanks was maintained between 7.2 and $9.0^{\circ} \mathrm{C}$. The photoperiod was $12 \mathrm{~L}: 12 \mathrm{D}$ and the salinity decreased from 31.08 to 30.32 during the course of the experiment.

Zooplankton collected daily in a light trap or by towing a $1 \mathrm{~m}$ net ( $64 \mu \mathrm{m}$ mesh) were passed through a $220 \mu \mathrm{m}$ screen to provide prey of suitable size. Organisms of that size fraction typically consisted of nauplii and metanauplii of cirripedes and copepods, polychaete trochophores, and mollusc veligers. Prey were introduced at densities of 2,5 and $10 \mathrm{ml}^{-1}$ several days before larvae absorbed their yolk sacs to ensure the development of efficient predatory behavior. A treatment where larvae received no food was also maintained. Daily counts of prey organisms in the tanks were made from samples of $3 \times 5 \mathrm{ml}$ aliquots taken from the surface, middle and bottom of the rearing tanks thus ensuring that the desired feeding levels were maintained throughout the $21 \mathrm{~d}$ duration of the experiment. We were able to maintain prey densities within \pm 0.5 organisms $\mathrm{ml}^{-1}$ of the desired levels. Tanks were periodically siphoned to remove dead prey and other detritus. Microscopic examination of ingested food revealed that average $(n=7)$ prey dimensions were $0.20 \mathrm{~mm}$ (SD $=0.03$ ) by $0.56 \mathrm{~mm}$ (SD $=0.05$ ) indicating that the size of prey was suitable. We assumed that feeding preference and food value were independent of prey type and that any differences in prey composition did not influence the indices measured. In any case, since fish in all treatments were offered prey from the same collection, dayto-day differences in prey composition would not confound prey density-related effects on larval condition. We also assumed that the composition of fish diet was independent of prey density. No cannibalism of fish was noted in any of the treatments.

No estimates of numbers of larvae surviving per day are available. However, with the exception of the starvation treatment, no differences in survival rates would be expected among the other 3 groups as the prey densities should have been adequate for survival, based on previous laboratory studies of larval cod (Laurence et al. 1981). Hence, given that the treatments were stocked with the same volume of eggs, the numbers of predators in the various treatments should be about equal.

Samples of larvae were removed at Experiment Day $0,4,9,15$ and 21 . We measured length (anterior tip of jaw to posterior tip of last muscle segment), body height (measured at the insertion of the pectoral fin, Koslow et al. 1985), wet weight after blotting with filter paper, and dry weight following drying in a convection oven $\left(24 \mathrm{~h}\right.$ at $\left.60{ }^{\circ} \mathrm{C}\right)$. All weights were determined to the nearest $0.1 \mu \mathrm{g}$ with a Cahn electrobalance. Of the 214 larvae for which morphometric data were collected, dry weights were obtained for only 41 . However, as wet weight and dry weight were significantly correlated ( $r=0.705, p<0.001$ ), wet weight was taken as a reliable indicator of body mass. An ocular micrometer was used to obtain linear measurements of live anaesthetized (2-phenoxyethanol at 1:10000 [V/ $\mathrm{V}]$ concentration) larvae to the nearest $0.01 \mathrm{~mm}$.

The ability of larvae reared at the various prey densities to avoid predation was simulated by the technique of Bailey \& Yen (1983). Using an automatic pipette set to withdraw $2 \mathrm{ml}$ of fluid, the distance at which $50 \%$ of the capture attempts were successful was determined from the relation of distance (tip of pipette to the head of the larva) versus the percent capture success. Measurements of predator avoidance were made using a $500 \mathrm{ml}$ graduated cylinder, with a ruler attached to the back. A normal level of indoor illumination was maintained. The pipette tip was brought slowly to the desired distance from the larva, with the tip oriented towards the dorsal surface of the larva's head. Fifteen capture attempts were made at each distance of $10,7.5,5$ and $2 \mathrm{~mm}$ from the larva. To reduce the possibility of fatigue-related effects, a fresh 
larva was used after every fifth capture attempt. The $50 \%$ capture distance was determined using graphic interpolation.

The condition of larvae was described using Fulton's condition factor $(\mathrm{K})$ :

$$
\mathrm{K}=\frac{\text { wet weight }(\mathrm{mg}) \times 1000}{\text { length }^{3}(\mathrm{~mm})}
$$

Buoyancy experiments were conducted at Day 0 (hatch), 4, 9 and 15 using $250 \mathrm{ml}$ graduated cylinders containing seawater of known salinities measured with an Autosal salinometer. Salinities of 27.936 , $30.014,31.976$ and 39.767 were prepared by dilution with distilled water or evaporation of Passamaquoddy Bay seawater of 31.976 salinity. During each set of measurements, the temperature of the samples was noted and the seawater densities calculated from the salinities and temperatures (Millero \& Poisson 1981). Five larvae from each of the 5, 2 and 0 prey $\mathrm{ml}^{-1}$ treatments (plus the 10 prey $\mathrm{ml}^{-1}$ treatment on Day 9) were selected randomly and anaesthetized in 1:5000 (V/V) 2-phenoxyethanol. Activity ceased after 1 to 2 min in the anaesthetic, but in all cases resumed within 1 min of transfer to fresh seawater. Once movement had ceased, larvae were rinsed in water of the test salinity, transferred using a pipette and slowly released in the centre of a graduated cylinder filled with water of identical salinity. The time required to sink or rise 20 to $40 \mathrm{~mm}$ at a constant rate was then noted with the aid of a stopwatch.

Data were analysed for each prey concentration treatment by plotting the average sinking rate in each salinity versus density of the water and a linear $\left(\sigma_{1}=\mathrm{a}\right.$ $+\mathrm{b}$ [sinking rate]) or power curve $\left(\sigma_{1}=\mathrm{a}\right.$ [sinking rate $]^{b}$ ) best fit was calculated for each sampling day and prey treatment (Table 1). The choice between power or linear regression was based on the highest

Table 1. Gadus morhua. Regressions of seawater density (as $\sigma_{1}$ ) on mean sinking rates of Atlantic cod larvae reared under varying prey densities, used to determine larval specific gravities. Larval specific gravities were then determined from these regressions with sinking rates set at 0

\begin{tabular}{|c|c|c|c|c|c|}
\hline Day & $\begin{array}{l}\text { Prey density } \\
\text { (no. } \mathrm{ml}^{-1} \text { ) }\end{array}$ & Regression & $I^{2}$ & $\mathrm{a}$ & b \\
\hline 0 & N/A & Linear & 0.95 & 23.79 & -1.82 \\
\hline \multirow[t]{3}{*}{4} & 5 & Linear & 0.97 & 24.40 & -1.86 \\
\hline & 2 & Linear & 0.98 & 23.12 & -1.70 \\
\hline & 0 & Linear & 0.93 & 23.75 & -1.66 \\
\hline \multirow[t]{4}{*}{9} & 10 & Linear & 0.98 & 24.07 & -2.91 \\
\hline & 5 & Linear & 0.94 & 22.87 & -2.16 \\
\hline & 2 & Linear & 0.71 & 22.28 & -2.58 \\
\hline & 0 & Power & 0.99 & 24.21 & -0.14 \\
\hline \multirow[t]{2}{*}{15} & 5 & Power & 0.99 & 26.25 & -0.15 \\
\hline & 2 & Power & 0.99 & 26.90 & -0.16 \\
\hline
\end{tabular}

regression coefficient. The density at neutral buoyancy in each treatment, assumed to represent the average larval specific gravity, was then determined by solving the resulting regression equation for a sinking rate of zero.

\section{RESULTS}

Yolk sac absorption was complete 6 to $8 \mathrm{~d}$ after hatching. After sampling on Day 9, no fish remained in the starvation treatment. In addition, an unexplained
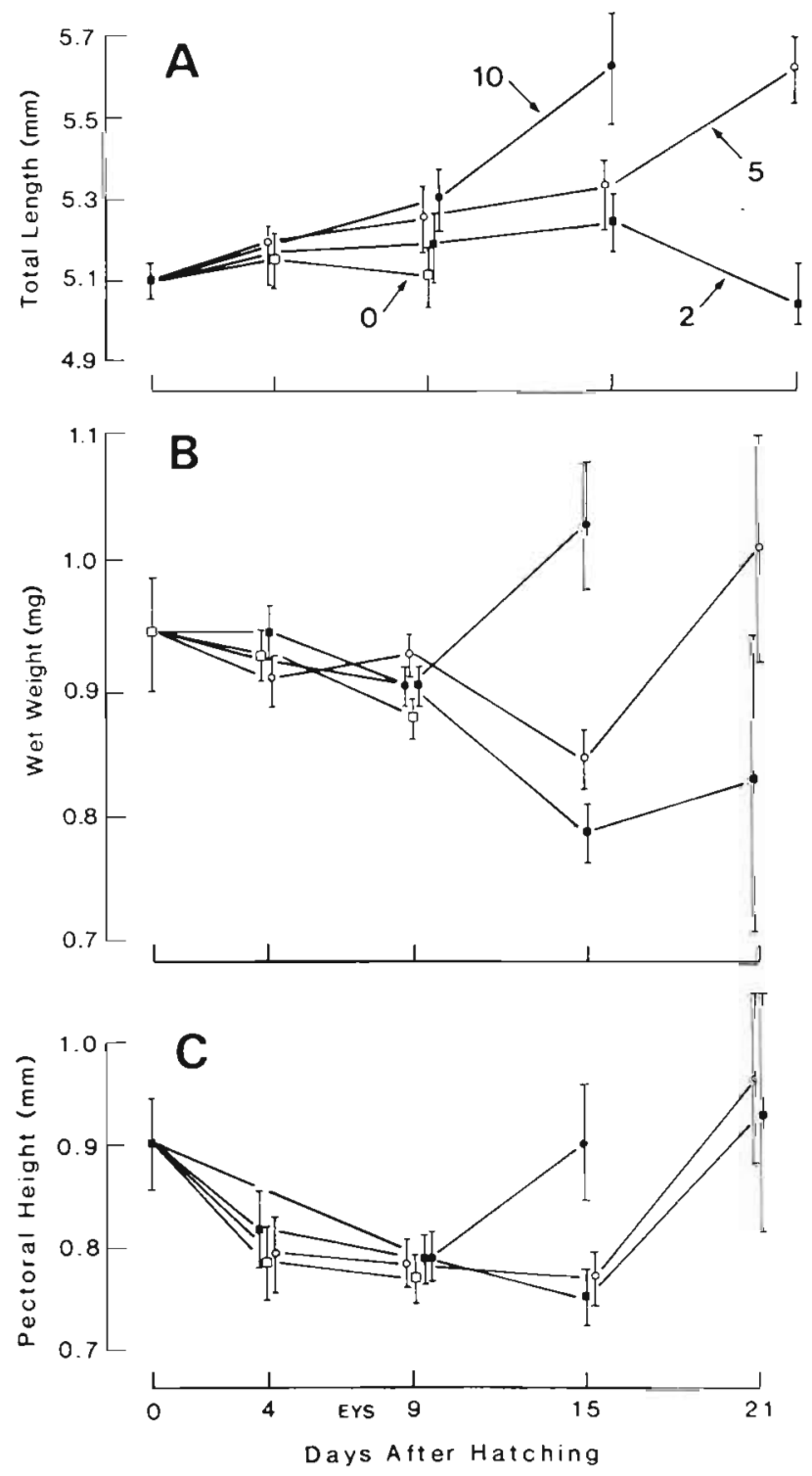

Fig. 1. Gadus morhua. Change in various morphometric features of Atlantic cod larvae reared in different prey densities, over the $21 \mathrm{~d}$ duration of the experiment. (A) Total length; (B) wet weight; (C) pectoral height. Plotted points are means of 5 to 20 larvae, with $\pm 1 \mathrm{SE}$ indicated. Treatments: ( 10 prey $\mathrm{ml}^{-1}$; (O) 5 prey $\mathrm{ml}^{-1}$; (E) 2 prey $\mathrm{ml}^{-1}$; (口) 0 prey $\mathrm{ml}^{-1}$ EYS: end yolk-sac stage 
high mortality occurred on Day 17 for the 10 prey $\mathrm{ml}^{-1}$ treatment, hence no sample was obtained at Day 21 for that group. After Day 9, the indicators of fish growth generally reflected the different levels of prey density (Fig. 1), with the 10 prey $\mathrm{ml}^{-1}$ treatment showing the fastest rate of growth. In addition, the onset of rapid growth occurred sooner in the 10 prey $\mathrm{ml}^{-1}$ treatment.

Fulton's $\mathrm{K}$ declined during the $21 \mathrm{~d}$ duration of the experiment for all treatments and did not appear to be correlated with the differing prey concentrations (Fig. 2). However, the ratio of body height to length

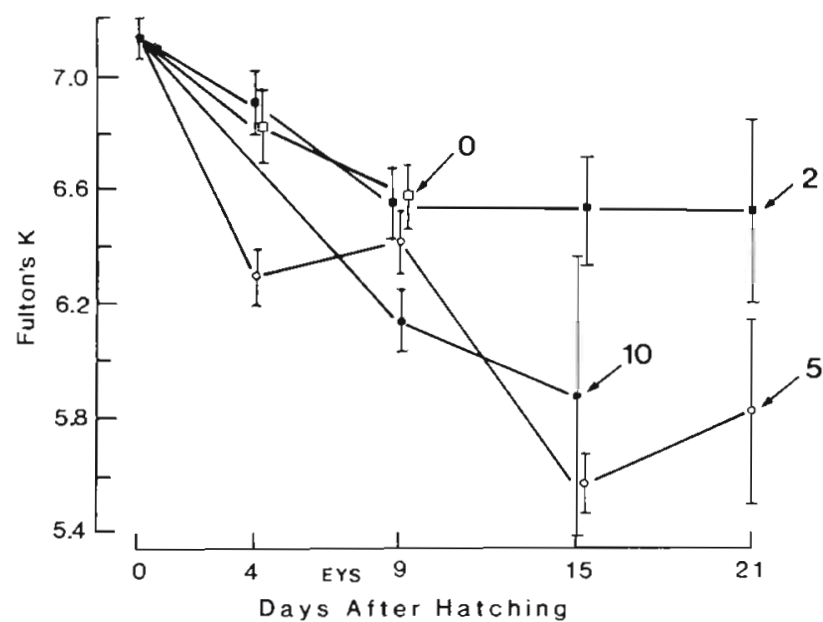

Fig. 2. Gadus morhua. Changes in Fulton's conditon factor over the $21 \mathrm{~d}$ experiment. Points are means of 5 to $20 \mathrm{cod}$ larvae, with $\pm 1 \mathrm{SE}$ indicated. Symbols as in Fig. 1

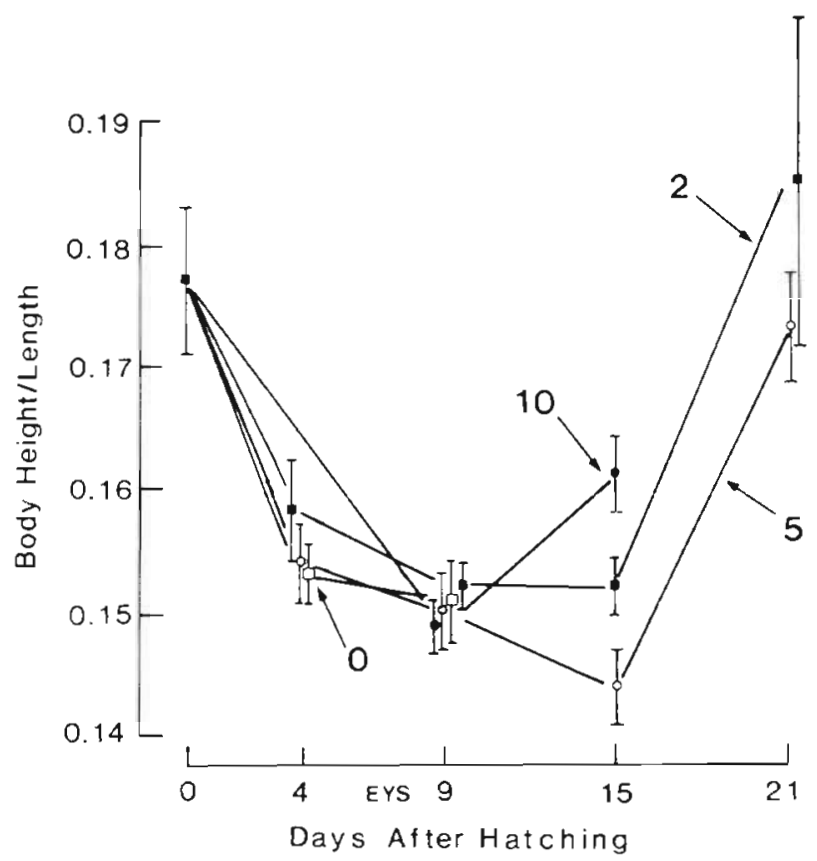

Fig. 3. Gadus morhua. Changes in body height (measured at the insertion of the pectoral fin) divided by total length, over the $21 \mathrm{~d}$ experiment. Plotted points are means 5 to 20 larvae, with $\pm 1 \mathrm{SE}$ indicated. Symbols as in Fig. 1 followed U-shaped curves for the fed groups, with increasing body depth per unit of length apparent after Day 9 for the 10 prey $\mathrm{ml}^{-1}$ treatment and Day 15 for the 5 and 2 prey $\mathrm{ml}^{-1}$ treatment (Fig. 3).

At Day 9 , the ability to avoid the simulated predator was proportional to prey density. Neither indicator of condition examined in this paper was positively correlated with the performance of larvae in predator avoidance (Fig. 4).

A maximum specific gravity (minimum of buoyancy) occurred during the yolk-sac stage, followed by decreasing specific gravity (increasing buoyancy) (Fig. 5). The decline of specific gravity was inversely related to prey density. The slight increase in specific gravity on Day 15 for larvae reared at 2 prey $\mathrm{ml}^{-1}$ may be an artifact attributable to the relatively small number of larvae surviving in that treatment.

Specific gravity was positively correlated with prey density at Day 9 (the time when the predator avoidance experiment was completed), indicating that the buoyancy of early stages of cod larvae may be directly related to prey density (Fig. $6, \mathrm{r}^{2}=0.99, \mathrm{p}<0.01$ ). At the salinity at which the eggs and larvae were reared (approximately 31 ), all larvae in treatments less than 10 prey $\mathrm{ml}^{-1}$ were somewhat positively buoyant.

\section{DISCUSSION}

Our data support the view that a single morphological criterion, such as Fulton's K, does not adequately describe the condition of early stages of larvae of marine fish. Differences in buoyancy and the ability to avoid predation observed at Day 9 were not reflected in the morphometric indices of condition (Fig. 2,3) on the corresponding dates. Theilacker (1978), in a laboratory study of jack mackerel Trachurus symmetricus, noted that while morphological criteria may reflect larval nutritional condition and could be considered reference parameters, no one criterion accurately identified larval condition on an individual basis. Theilacker attributed the lack of sensitivity of morphometric measurements to natural variability or more probably the rapid morphological changes which occur in larval fishes. She further noted the unpublished work of Zweifel for feeding northern anchovy Engraulis mordax larvae, where the condition factor (weight/length ${ }^{3}$ ) was neither constant nor monotonic even when food densities were carefully controlled. Blaxter (1971) found that Fulton's condition factor for larval herring Clupea harengus was negatively correlated with the biomass of planktonic food in the sea. Laurence (1974) found that in laboratory-reared haddock larvae Melanogrammus aeglefinus, condition factor was randomly associated with prey density. 
Fig. 4. Gadus morhua. Average distance at which $50 \%$ of capture attempts of larval Atlantic cod were successful (Experiment Day 9). Also shown is Fulton's $\mathrm{K}$ ([O], inside right axis) and body height at pectoral fin insertion/total length ([a], outside right axis). $\mathrm{N}=20$ for calculation of each condition index; $\pm 1 \mathrm{SE}$ indicated

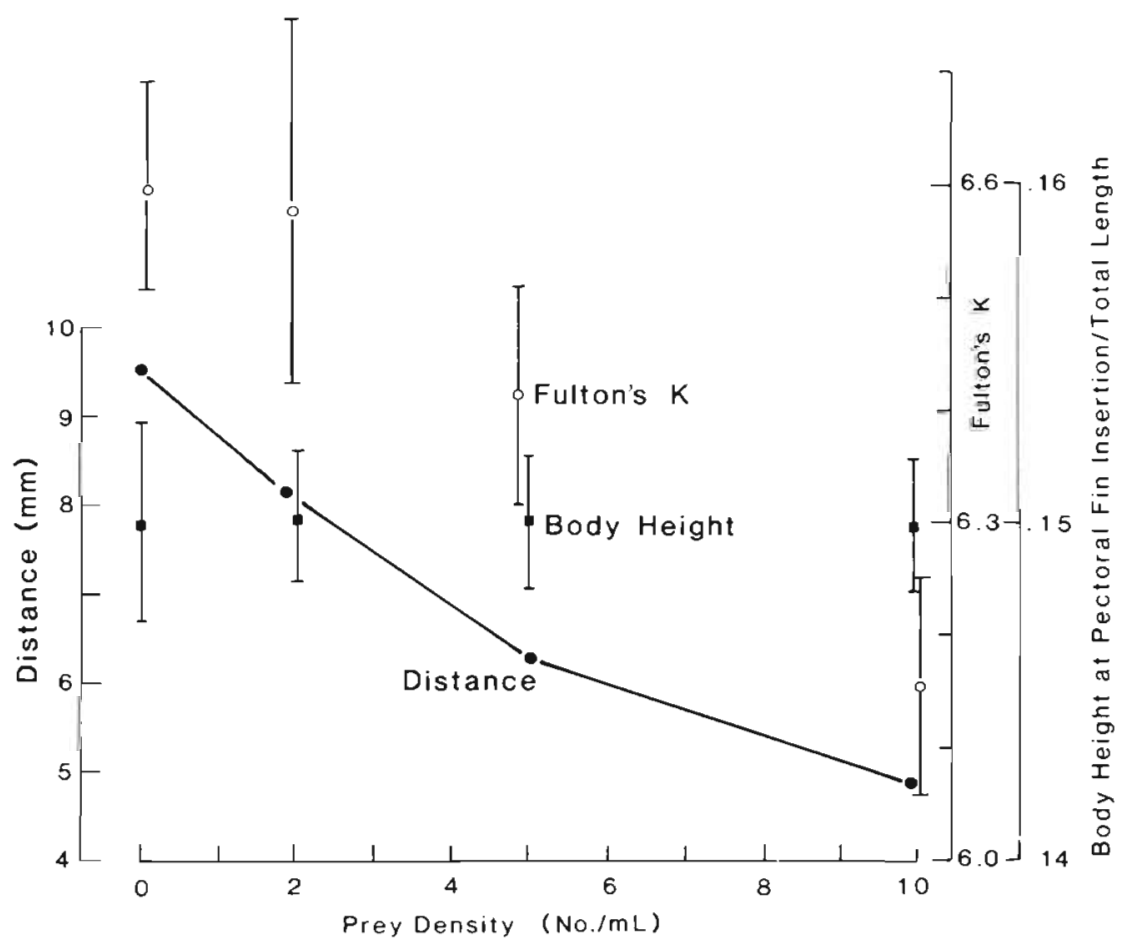

These results in addition to those shown in Fig. 2 provide evidence of the inappropriateness of employing single morphological indicators of condition without reference to other criteria such as buoyancy, as suggested below. We support the view of Theilacker (1978) that rapid morphological changes, such as those apparent during the transition to exogenous feeding, may reduce the applicability of morphological-based indices of condition. However, such indices may not perform as erratically during later stages of fishes' life history.

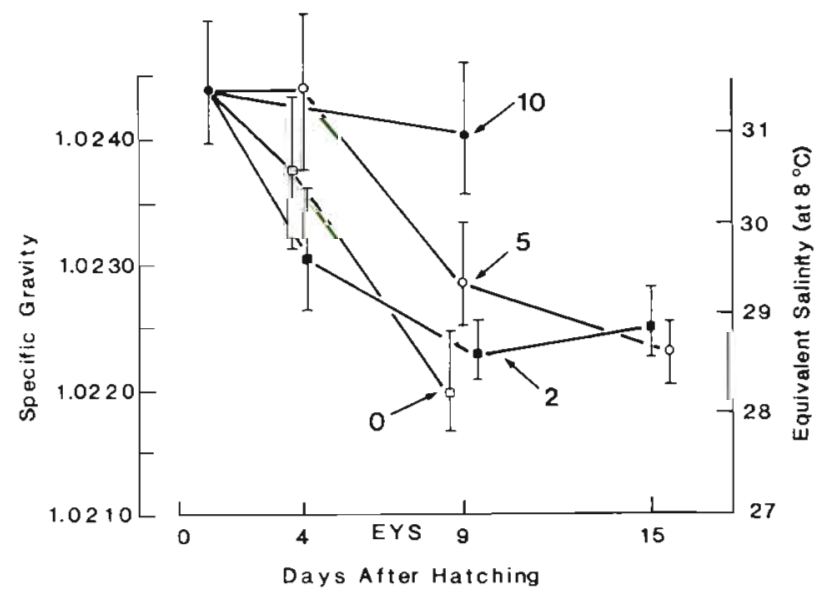

Fig. 5. Gadus morhua. Changes in mean specific gravitiy of Atlantic cod larvae reared in the 4 prey densities with time: symbols as in Fig. 1. Vertical bars \pm 1 SE. Equivalent salinity calculated at an average rearing temperature of $8{ }^{\circ} \mathrm{C}$ is presented on the right axis. EYS: end yolk-sac stage
Wet weight and pectoral height generally declined until Day 15, except in the 10 prey $\mathrm{ml}^{-1}$ treatment (Fig. 1). Initially, such declines were probably due to yolk sac absorption. However, after the transition to exogenous feeding at about Day 7 , declines in pectoral height and wet weight may have been attributable to a period of developing efficient predatory behavior, with fish in the treatment with the highest prey density adopting such behavior more rapidly.

The ratio of body height to total length (Fig. 3) appeared to be better correlated with morphometric data shown in Fig. 2 than was Fulton's $K_{\text {, and indicated }}$ that condition of the larvae was increasing after Day 15. Wyatt (1972), working with plaice Pleuronectes platessa held under laboratory conditions, showed that

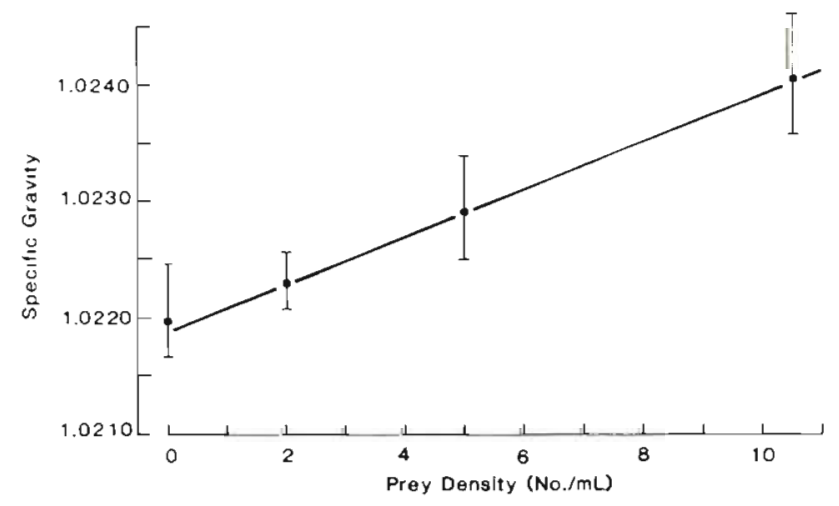

Fig. 6. Gadus morhua. Average larval specific gravity of larval Atlantic cod at the 4 prey densities at Experiment Day 9. Vertical bars $\pm 1 \mathrm{SE}$ 
the relative growth of body height and length responded rapidly to changes in food density and advocated the use of the body height:total length ratio as a condition factor. Koslow et al. (1985) found that among 12 morphometric indices of condition for cod larvae sampled in the field, the best correlations with environmental variables such as numbers of copepod nauplii were with body height. However, even measures of body height failed to indicate apparent differences in condition at Day 9 evident from the predator avoidance and buoyancy experiments.

Blaxter \& Ehrlich (1974) suggested that the tendency for specific gravity of larvae to decrease with starvation (and therefore the buoyancy to increase) was due to increased water content and in particular, to the decreased protein content of the tissues. Our results are consistent with this hypothesis, with Iarvae reared at higher prey densities having progressively greater specific gravities. We presume this is due to the low water and higher protein content of tissues that occurs with more favorable food conditions. As growth continues, specific gravity of well-fed larvae can be expected to increase due to increased skeletal ossification and the development of functional organ systems.

The results of the buoyancy experiments indicate that for larvae of a given size or age, buoyancy may be a better indicator of condition than those based on morphometric data. The pattern of specific gravity on Day 9 is inverse to that of Fulton's K (Fig. 2) and directly related to the ability to avoid predation (Fig. 4). We suggest that higher specific gravity of larvae reared under the higher prey densities implies a lower water content and higher protein content in the tissues, which allows the larvae to better avoid predation.

Following the methods of Bailey \& Yen (1983), our simulated predator most closely resembled the behavior of an ambush predator. However, as noted by $\varnothing$ iestad (1985), in addition to active predation by other fish, cod larvae are also subject to predation by hydromedusae. In such instances, physical contact may be sufficient to cause mortality (Baily \& Batty 1983) and encounters may not be a function of larval condition.

The presence of a functional swimbladder in Atlantic cod larvae could conceivably complicate the interpretation of the buoyancy experiments. Ellertsen et al. (1980) found that the swimbladder developed in larvae greater than $5 \mathrm{~mm}$ only if they had received adequate food. However, it is not clear at what stage of development the simbladder becomes filled and fully functional. In accordance with Ellertsen et al. (1980), we have assumed that the simbladder did not affect the buoyancy determinations in our experiments, particularly as the fish were anaesthetized. Moreover, in physoclistous fish such as cod, filling of the air bladder accurs with the passage of gas from the rete mirabile
(Marshall 1965), a process which does not occur rapidly (Norman \& Greenwood 1963). Hence, it is unlikely that fish were able to compensate for a tendency to sink using their simbladders over the relatively short period that the measurements were made. Even if the swimbladder was actively functioning, it would tend to mask rather than exaggerate differences in sinking rate.

The tendency for poorly fed larvae to be more buoyant (lower specific gravity) has important implications. Less well-fed larvae are probably subject to higher natural mortality through predation, which might be exacerbated by their occurrence in the well-lit surface waters. The possibility that poorly fed larvae may also be more vulnerable to net capture was raised by Arthur (1956). Experiments comparing the condition of larvae caught in conventional net tows through near-surface waters to that of larvae caught in a gear type which largely eliminates the bias of net avoidance (such as a plankton purse seine: Burdick 1969) might be useful in determining the magnitude of the problem.

Acknowledgements. We thank A. Campbell, Canada Department of Fisheries and Oceans, and J. A. Koslow, Dalhousie University, for their critical reviews of an earlier version of this manuscript. K. Howes, R. Losier and P. Perley maintained the brood stock, assisted with the buoyancy determinations and the with collection of prey, respectively. Discussions with J. A. Koslow, who suggested many aspects of the experimental design, were particularly appreciated. We also thank Barbara Garnett and Brenda Fawkes for word processing, Frank Cunningham for preparation of the figures and Darlene Warren for proofreading the final draft.

\section{LITERATURE CITED}

Arthur, D. K. (1956). The particulate food and the food resources of the larvae of three pelagic fishes, especially the Pacific sardine, Sardinops caerulea (Girard). Ph. D. thesis, Univ. Calit., Scripps Institute of Oceanography, La Jolla

Bailey, K. M., Batty, R. W. (1983). A laboratory study of predation by Aurelia aurelia on larval herring (Clupea harengus): experimental observations compared with model predictions. Mar. Biol. 72: 295-301

Bailey, K. M., Yen, J. (1983). Predation by a carnivorous marine copepod, Euchaeta elongata Esterly, on eggs and larvae of the Pacific hake, Merluccius productus. J. Plankton Res. 5: 71-82

Blaxter, J. H. S. (1971). Feeding and condition of Clyde herring larvae. Rapp. P.-v. Réun. Cons. int. Explor Mer 160: $128-136$

Blaxter, J. H. S., Ehrlich, K. F. (1974). Changes in behaviour during starvation of herring and plaice larvae. In: Blaxter, J. H. S. (ed.) The early life history of fish, Springer-Verlag, New York, p. 575-588

Buckley, L. J. (1979). Relationships between RNA-DNA ratio, prey density and growth rate in Atlantic cod /Gadus morhua) larvae. J. Fish. Res. Bd Can. 36: 1497-1502

Buckley, L. J. (1980). Changes in ribonucleic acid, deoxyribonucleic acid, and protein content during ontogenesis 
in winter flounder, Pseudopleuronectes amencanus, and effect of starvation. Fish. Bull. U. S. 77: 703-708

Burdick, J. E. (1969). The feeding habits of nehu (Hawaiian anchovyl larvae. M. S. thesis, Univ. of Hawai, Manoa

Coombs, S. H. (1981). A density-gradient column for determining the specific gravity of fish eggs, with particular reference to eggs of the mackerel (Scomber scombrus). J. mar, biol. Ass. U. K. 63: 101-106

Coombs, S. H., Fosh, C. A., Keen, M. A. (1985). The buoyancy and vertical distribution of eggs of sprat (Sprattus sprattus) and pilchard (Sardina pilchardus). J. mar. biol. Ass. U. K. 65: 461-474

Ehrlich, K. F. (1974a). Chemical changes during growth and starvation of larval Pleuronectes platessa. Mar. Biol. 24: $39-48$

Ehrlich, K. F. (1974b). Chemical changes during growth and starvation of herring larvae. In: Blaxter, J. H. S. (ed.) The early life history of fish. Springer-Verlag, Berlin, p. 301-323

Ehrlich, K. F., Blaxter, J. H. S., Pemberton, R. (1976). Morphological and histological changes during the growth and starvation of herring and plaice larvae. Mar. Biol. 35: 105-118

Ellertsen, B., Solemdal, P., Strømme, T., Tilseth, S., Westgård, T., Moksness, E., Øiestad, V. (1980). Some biological aspects of cod larvae (Gadus morhua L.). FiskDir. Skr. Ser. HavUnders. 17: 29-47

Hjort, J. (1914). Fluctuations in the great fisheries of northern Europe viewed in the light of biological research. Rapp. P.-v. Réun. Cons. int. Explor. Mer 20: 1-228

Hjort, J. (1926). Fluctuations in the year classes of important food fishes. J. Cons. int. Explor. Mer 1: 5-38

Koslow, J. A., Brault, S., Dugas, J., Fournier, R. O., Hughes, P. (1985). Condition of larval cod (Gadus morhua) off southwest Nova Scotia in 1983 in relation to plankton abundance and temperature. Mar. Biol. 86: 113-121

Laurence, G. C. (1974). Growth and survival of haddock (Melanogrammus aeglefinus) larvae in relation to planktonic prey concentration. J. Fish. Res. Bd Can. 31: $1415-1419$

Laurence, G. C., Smigielski, A. S., Halavik, T. A., Burns, B. R. (1981). Implications of direct competition between larval cod (Gadus morhua) and haddock (Melanogrammus aeglefinus) in laboratory growth and survival studies at different food densities. Rapp. P.-v. Réun. Cons. int. Explor. Mer 178: 304-311

LeCren, E. D. (1951). The length-weight relationship and seasonal cycle on gonad weight and condition in perch (Perca fluviatilis). J. Anim. Ecol. 20: 201-219

Marshall, N. B. (1965). The life of fishes. Weidenfeld and Nicolson, London

May, R. C. (1974). Larval mortality in marine fishes and the critical period concept. In: Blaxter, J. H. S. (ed.) The early life history of fish. Springer-Verlag, New York, p. 3-19

Methot, R. (1982). Growth rates and age distributions of larval and juvenile northern anchovy, Engraulis mordax, with inferences on larval survival. Ph. D. thesis, Univ. of California, San Diego

Millero, F. J., Poisson, A. (1981). International one-atmosphere equation of state of seawater. Deep Sea Res. 28 $625-629$

Norman, J. R., Greenwood, P. H. (1963). A history of fishes. Ernest Benn, London

O'Connell, C. P. (1980). Percentage of starving northern anchovy, Engraulis mordax, larvae in the sea as estimated by histological methods. Fish. Bull. U. S. 78: 475-489

O'Connell, C. P., Paloma, P. A. (1981). Histochemical indications of liver glycogen in samples of emaciated and robust larvae of the northern anchovy, Engraulis mordax. Fish. Bull. U. S. 79: 806-812

Oiestad, V. (1985). Predation on fish larvae as a regulatory force, illustrated in mesocosm studies with large groups of larvae. North Atlantic Fisheries Organization Scientific Council Studies 8: 25-32

Power, J. H. (1984). Advection, diffusion, and drift migrations of larval fish. In: McCleave, J. D., Arnold, G. P., Dodson, J. J., Neill, W. H. (ed.) Mechanisms of migration in fishes. Plenum Press, New York, p. 27-37

Shelbourne, J. E. (1957). The feeding and condition of plaice larvae in good and bad plankton patches. J. mar. biol. Ass. U. K. 36: 539-552

Sundby, S. (1983). A one-dimensional model for the vertical distribution of pelagic fish eggs in the mixed layer. Deep Sea Res. 30: 645-661

Sundnes, G., Leivestad, H., Iversen, O. (1964). Buoyancy determination of eggs of the cod (Gadus morhua L.). J. Cons. int. Explor. Mer 29: 249-252

Theilacker, G. H. (1978). Effect of starvation on the histological and morphological characteristics of jack mackerel Trachurus symmetricus, larvae. Fish. Bull. U. S. 76 : $403-414$

Wyatt, T. (1972). Some effects of food density on the growth and behaviour of plaice larvae. Mar. Biol. 14: 210-216

This article was submitted to the editor; it was accepted for printing on June 25,1986 